\title{
Backliners: Roles of Science Educators in the Post-COVID Milieu
}

\author{
Danilo V. Rogayan Jr. ${ }^{1 *}$, Marshall James P. Dantic ${ }^{1}$
}

${ }^{1}$ College of Teacher Education, President Ramon Magsaysay State University, PHILIPPINES

*Corresponding Author: danrogayan@gmail.com

Citation: Rogayan Jr., D. V., \& Dantic, M. J. P. (2021). Backliners: Roles of Science Educators in the Post-COVID Milieu. Aquademia, 5 (2), ep21010. https://doi.org/10.21601/aquademia/11053

\section{ARTICLE INFO}

Received: 9 Mar. 2021

Accepted: 3 May 2021

\begin{abstract}
COVID-19 pandemic has disrupted the global environment. It has affected almost all aspects of society from cultural, economic, educational, to social factors. This narrative inquiry explored science educators' perspectives on the vital roles they would play in the post-COVID setting. Sixteen teachers from different educational institutions were purposively selected to take part in this qualitative investigation. The participants wrote their short narratives on their significant role as science teachers after the COVID-19 pandemic. Six themes emerged as roles of the science teachers in the post-COVID era; these include (1) science communicator; (2) critical thinker; (3) knowledge creator; (4) disruptive innovator; (5) advocate against misinformation; and (6) futureready educator. A conceptual paradigm is designed to describe the vital roles of science teachers in the postpandemic era in the context of the VUCAD ${ }^{2}$ (volatile, uncertain, complex, ambiguous, diverse, and disruptive) world. Implications of the findings to science education in the post-pandemic setting are discussed in the paper.
\end{abstract}

Keywords: COVID-19, narrative inquiry, science education, new normal, post-COVID era

\section{INTRODUCTION}

The COVID-19 (Coronavirus disease 2019) pandemic has caused massive disruption in different societal dimensions. Its impacts have devastated various dimensions such as cultural (Bruns et al., 2020; Noel, 2020), educational (Cahapay, 2020; Cuaton, 2020; Karakaya et al., 2021; Keswani et al., 2020; Marinoni et al., 2020; Moralista \& Oducado, 2020; Rogayan et al., 2021; Sahu, 2020; Sintema, 2020; Toquero, 2020a; Tria, 2020), environmental (Muhammad et al., 2020; Shakil et al., 2020; Toquero, 2020b; Verma \& Prakash, 2020); political (Dodds et al., 2020; Woods et al., 2020); socio-economic (Acikgoz \& Gunay, 2020; Atalan, 2020; Fernandes, 2020; Radwan \& Radwan, 2020), socio-psychological (Pfefferbaum \& North, 2020; Restubog et al., 2020; Sokolovskaya, 2020; Sundarasen et al., 2020; Tee et al., 2020; Usak et al., 2020), and socio-environmental dimension (Paital, 2020; Paital \& Agrawal, 2020; Paital et al., 2020). The current pandemic has aggravated the $\mathrm{VUCAD}^{2}$ world we live in, characterized by volatility, uncertainty, complexity, ambiguity, diversity, and disruption. VUCAD ${ }^{2}$ serves as the new normal in education, which describes the chaotic, turbulent, rapidly changing educational landscape (Morales, 2019; Morales, 2020; Waller et al., 2019). Further, significant global events such as disruptive technologies, fourth industrial revolution (FIRe), new set of future work skills, and the present COVID-19 global contagion brought the education realm into the context of
$\mathrm{VUCAD}^{2}$ (Morales, 2020). This VUCAD ${ }^{2}$ world will continue to challenge every aspect of society in the post-pandemic setting.

The occurrence of COVID-19, a newly-discovered infectious viral disease, has led to a global health emergency, which was later declared a pandemic by WHO on February 11, 2020. Madhav et al. (2017) mentioned that pandemics could cause significant, widespread increases in morbidity and mortality and have disproportionately higher mortality impacts. Once a pandemic has started, a coordinated response should be implemented to maintain social awareness, public health communication, reducing transmission, and responding to the infected. Now, the COVID-19 outbreak has put our world to a standstill with unparalleled and unforeseen impacts in our lives (United Nations World Tourism Organization, 2020).

In light of these concerns, science education's role is very critical in navigating the post-COVID era. The science-based and research-based concepts are essential inputs to policy formulation and government guidelines concerning the COVID-19 pandemic. Science educators have played crucial roles in providing quality science learning among the students. For the post-pandemic setting, science educators play more significant roles in navigating a new normal post-COVID era. The medical and health professionals are considered 'frontliners,' as they battle in the forefront of the virus. However, teachers are regarded as 'backliners.' The concepts and ideas imparted by teachers among the learners from the basic definition of a virus to its mode of transmission, are 
essential for better preparedness, prevention, and response in health emergencies and pandemics. Science education cuts across the persistent divide of natural sciences and social science, potentially uniquely positioned to support new generations' understanding and engagement and address the social, economic, and environmental dimensions of these global challenges (Adams et al., 2018).

Reiss (2020) stated that the history and philosophy of science (HPS) regarding COVID-19 contributes to science education and vice versa. It provides opportunities to introduce the students to sociological thinking, examine data, and question human practices (Reiss, 2020). Jermolajeva et al. (2019) described that teachers are at the center of many socially significant interactions between people, such as the interaction of generations, people of diverse backgrounds and different education levels, and various professions. Relative to this, Unicef Australia (2020) encourages teachers that sharing accurate information and science-based facts about COVID-19 could help diminish student's fears and anxieties around the disease and support their ability to cope with any secondary impacts in their lives. Teachers also transform lives by leaving a positive mark in students' lives. Also, educators broaden the horizons by curing students' ignorance (Rogayan, 2018.)

Undoubtedly, science teachers have significant niche in a socio-ecological system. Bourn (2016) emphasized that teachers are critical actors of societal change and great facilitators of global learning. He averred that teachers are bringers of positive change to people's lives and natural leaders in the community who can be a resource of information on civic affairs. Scholarly literature also enumerated the social roles of teachers specifically Science teachers. Teachers are seen as agents of societal change (Butera et al., 2021; Cappy, 2016; Ilisko, 2007; Kass \& Miller, 2011; Mendenhall et al., 2021; So \& Park, 2020), agents of inclusion and social justice (Pantic \& Carr, 2017; Pantic \& Florian, 2015), agents of sustainable peace, social cohesion and development (Novelli \& Sayed, 2016; Rubagiza et al., 2016), and communicators of information (Esteve, 2000). More than being facilitators of learning and disseminators of knowledge, teachers play a pivotal role in the community development, societal improvement, national progress and global sustainability.

This paper focused its inquiry on exploring the significant roles that science educators could play in the post-COVID milieu, revealing their involvement and contributions to society and the academic community. This study hopes to fill the gap on the dearth of studies concerning science educators' role in the post-COVID era and in the VUCAD ${ }^{2}$ world.

\section{METHODOLOGY}

\section{Research Design}

To achieve the objective of this study, a qualitative narrative inquiry research design was employed. The purpose of narrative inquiry is that "stories are collected as a means of understanding experience as lived and told, through both research and literature" (Savin-Baden, \& Niekerk, 2007, p. 459). In this paper, the researchers explored the roles of science educators as vital players on the post-COVID 19 era.
The participants were asked the key question: What are the crucial roles of science educators in the post-COVID milieu? The researchers enriched the discussion of the narratives with supporting literature.

\section{Participants}

The study purposely selected 16 educators teaching sciences in different institutions in the Philippines $(n=9)$, Brazil ( $n=1)$, Canada (1), Nigeria (2), Oman ( $n=1)$, Pakistan $(n=1)$, and Venezuela $(n=1)$. The participants are teachers in primary and higher institutions handling science-related courses. The researchers reached the data saturation at the $16^{\text {th }}$ narrative which signaled the researchers to stop the data collection. Data saturation refers to the point in the research process when no new information is discovered in data analysis, and this redundancy signals to researchers that data collection may cease (Faulkner \& Trotter, 2017, p. 1).

\section{Data Collection and Tool}

For data collection, the researchers posted the key question in the ResearchGate question bulletin on March 30, 2020. Responses were accepted until July 15, 2020. Other narratives came from the researchers' interview to science teachers in the Philippines through Facebook messenger and Google Meet. The participants' narratives were encoded verbatim, and no translation was done as the participants answered the questions in the English language. The researchers asked an informant feedback to ensure the accuracy of the responses.

\section{Data Analysis}

To analyze the qualitative data, the researchers did manual coding and employed the strategy used by Miles et al. (2014). Such a strategy involves three concurrent processes: 1) data condensation, 2) data display, and 3) drawing and verifying conclusions. In data condensation, the researchers selected, focused, simplified, abstracted and transformed the narratives of the participants. The collected narratives were typed, read and summarized. Then, in the data display, they organized and compressed assembly of information that permits conclusion drawing through creating analysis matrices with the emerging themes and sample significant statements. Lastly, the researchers proceeded with the step of drawing and verifying conclusions. Conclusion drawing involves stepping back to consider what the analyzed data mean and to assess their implications for the questions at hand while verification entails revisiting the data as many times as necessary to crosscheck or verify these emergent conclusions (Miles et al., 2014). An iterative procedure was made in this study since qualitative data analysis is nonlinear in nature (Lochmiller \& Lester, 2017). To further ensure the accuracy and reliability of the data, an inter-rater reliability in theme identification and member-checking were employed.

\section{FINDINGS AND DISCUSSION}

The present COVID-19 pandemic has indeed disrupted various dimensions of society, including science education. The role of science teachers during and after a pandemic is vital to ensure the continuity of education, contribute to minimizing the viral transmission through science teaching 
Table 1. Roles of Science Educators on Post-COVID Milieu

\begin{tabular}{lll}
\hline Generated Theme & Sample Significant Statement & Theme Description \\
Communicator & $\begin{array}{l}\text { Science educators must freely share their learnings and thoughts } \\
\text { regarding COVID 19 to help the community be equipped with } \\
\text { important knowledge. This knowledge may indeed be useful, and } \\
\text { bring a more systematic response from the citizens. (P16) }\end{array}$ & $\begin{array}{l}\text { This focuses on the role of science educators in } \\
\text { bridging the gap between science and the public by } \\
\text { disseminating and explaining fundamental and } \\
\text { understandable science concepts. }\end{array}$ \\
\hline Critical Thinker & $\begin{array}{l}\text { Teachers may go beyond learning the virus itself into other related } \\
\text { learning opportunities like understanding how the economy is } \\
\text { connected with pandemics and how such relationships work, with } \\
\text { real examples happening around us to compare. (P06). }\end{array}$ & $\begin{array}{l}\text { Thalyzing factual evidence and information to } \\
\text { form an unbiased judgment and evaluation. }\end{array}$ \\
\hline $\begin{array}{lll}\text { Knowledge Creator } \\
\text { fhis is a great opportunity to show how we can inform ourselves } \\
\text { and others with scientifically appropriate sources. (P01). }\end{array}$ & $\begin{array}{l}\text { This pertains to science teachers' role in creating } \\
\text { new knowledge through research and employing } \\
\text { the scientific method. }\end{array}$ \\
\hline $\begin{array}{lll}\text { Disruptive Innovator } \\
\text { Enlighten the general public on the negative effects of the virus on }\end{array}$ & $\begin{array}{l}\text { This describes how science educators bring about } \\
\text { change and innovation into the system, which } \\
\text { the process of teaching and learning, and also restructure the } \\
\text { curriculum statement (P04). }\end{array}$ & $\begin{array}{l}\text { goes outside the conventional ways and then } \\
\text { improve over time. }\end{array}$ \\
\hline $\begin{array}{l}\text { Advocate against } \\
\text { Misinformation }\end{array}$ & $\begin{array}{l}\text { By being equipped with scientific knowledge, the people will avoid } \\
\text { inappropriate information, that somehow leads to catastrophic } \\
\text { public panic and mistakes (P16). }\end{array}$ & $\begin{array}{l}\text { This focuses on the educators' role in voicing out } \\
\text { against false news and inaccurate information. }\end{array}$ \\
\hline $\begin{array}{l}\text { Future-Ready } \\
\text { Educator }\end{array}$ & $\begin{array}{l}\text { Improve the science education by making it more practical not } \\
\text { theoretical for the students. Use COVID experience as inspiration } \\
\text { on its drastic change (P15). }\end{array}$ & $\begin{array}{l}\text { This deals with how science teachers morph into } \\
\text { the complexity of the present and future } \\
\text { educational landscape. }\end{array}$ \\
\hline
\end{tabular}

and information dissemination, and be proactive members of the community by assuming different roles identified in the present study.

To have a glimpse of the themes culled from the 16 science educators' narratives, a text table is presented (Table 1) with a narrative discussion.

\section{Science Communicator}

One indispensable role of science teachers is a science communicator. Several teachers have echoed this role to be more evident in the post-COVID milieu. Science teachers could bridge the gap between the science and the public by disseminating and explaining fundamental and understandable science concepts. This could be done through classroom instruction, policy brief formulation and dissemination, research presentations, and even public forums. A notable response mentioned that science educators 'must freely share their learnings and thoughts regarding COVID 19 to help the community be equipped with important knowledge (P16).' One participant (P01) stated,

Science teachers must be encouraged to explain their epistemic cognitive processes, including how they inform themselves. Students are still learning to decide what makes something scientifically correct and it is getting harder and harder to make these distinctions; it's not only about credible sources but also about making sound decisions about how data is interpreted.

The way teachers communicate science should be clear and precise for the students and the community people to understand specifically concerning pandemic and healthrelated issues affecting society. The teachers' way of imparting research-based and scientifically-verified information could lead to sound decisions and help the community respond well about a particular situation. A related statement was uttered by one participant (P10), teachers must 'raise awareness by explaining the cause, impacts, risks of diseases that lead to a pandemic.' In consonance, another participant (P14) believes that a science teacher has a 'fundamental role in promoting scientific literacy.' Since many countries in the world believe that the COVID-19 pandemic is a hoax, people tend not to practice physical distancing and wear face masks as they 'believe in populist leaders who deny science.' Teachers of science have important roles to play to enhance students' scientific literacy, specifically epidemics and pandemics. Reiss (2020) reiterated the position of interdisciplinarity in science lessons when discussing socio-scientific topics and issues intended to increase scientific literacy.

Using 'clear and systematic yet approachable informative materials or literature regarding COVID-19 must be shared to the general public' as articulated by participant 17. As a science communicator, teachers may design materials that use layman's language to understand scientific jargon and technical terms better. Moreover, another participant shared, 'science educator must find resources to provide information to his/her classes regarding safety precautions from the viruses that can cause diseases' (P11). Relatedly, Participant 6 mentioned integrating concepts of 'prevention as a mechanism for becoming healthy.' He added that science teachers could communicate to students by teaching the different types and mechanisms of disease prevention and the importance of handwashing, personal hygiene, and isolation in preventing infectious diseases. Sharing health and safety protocol to the students and the community is significant, specifically in the post-pandemic setting, to prevent future occurrence of epidemics and pandemics.

Burns et al. (2003) explained that science communication aims to improve public scientific awareness, understanding, literacy, and culture. Science teachers have important roles to play in disseminating fact-based data, in enriching and expanding public knowledge on socio-scientific issues, and in promoting cultural transformation. 


\section{Critical Thinker}

A critical thinker is another role identified by science teachers that they intensively assume in the post-COVID crisis. Teachers' role in analyzing factual evidence and information to form an unbiased judgment and evaluation has been emphasized to be strengthened after the pandemic. As critical thinkers, teachers must go beyond content knowledge. A salient response from one participant stated, 'teachers may go beyond learning about the virus itself into other related learning opportunities like understanding how the economy is connected with pandemics and how such relationships work, with real examples happening around us to compare' (P06).

Participant 6 also mentioned the role of social media in the perception of people. Teachers must make sure that the social media post is research-based and factual. Another participant pointed out to be critical of the impact of politics in science regarding the current pandemic. The COVID-19 pandemic enables students to perceive how science, economics, and politics inter-relate (Reiss, 2020). Asking difficult and essential questions to school administrators and even local and national leaders is vital as part of science teachers' social engagement. Korkmaz et al. (2017) emphasized that teachers must develop students' computational thinking skills, including creativity, algorithmic thinking, collaboration, critical thinking, problem-solving, and communication.

One of the participants mentioned, 'reflect on what happened, why it happened, how it happened. Reflect on the importance of social distancing and quarantine measures and how it helped slow the virus' (P10). To enhance students' critical thinking, teachers may use high-order thinking questions regarding social issues such as pandemic emergence. Additionally, Participant 12 shared, 'ask the learners of the values they have reflected on while on government-mandated quarantine measure. Teachers must promote reflective, rational, and critical thinking in teaching the concepts of science. Developing holistic learners who are inquisitive about science; who are problem solvers, and creative, self-perpetuating individuals has become one of the most important science education goals (Korkmaz et al., 2020).

Critical thinking is one of the core goals of education to produce dependent and rational thinkers and efficient citizens in this contemporary society (Haghparast et al., 2014). Teachers need to be critical thinkers in this society, a society which relentlessly confronts significant emerging issues. On the other hand, teachers should replicate this role to their students and to the public in general. Cultivating critical thinking requires the help of teachers in the context of education. Teachers can help students develop their critical thinking skills, enhance their assessment of evidences, improve how they evaluate facts from hoaxes, and assist them in formulating conclusions.

\section{Knowledge Creator}

Another role identified in this study is knowledge creator. This role of science teachers is about creating new knowledge by conducting investigation and research using scientific method rudiments. Participant reiterated that "this is a great opportunity to show how we can inform ourselves and others with scientifically-appropriate sources. This mirrors teachers' role in providing scientific and reliable data and information to the community based on research conducted. The study will yield factual results that can influence policies and compel the government leaders to act accordingly regarding the current and future COVID-19 situation. Teachers need to involve and reinforce the research, assessment, and strategic planning efforts to document best practices, increase evidence-based processes, and advance student learning amid the pandemic and in the post-pandemic era (Toquero, 2020a).

Participant 8 shared that science teachers must be 'more active in teaching the relationships of science, technology, and society (STS) and must find good information sources.' This suggests that science teachers must use research-based teaching as an instructional technique in teaching special topics concerning science and society. The use of reliable and credible sources can come from scientific research articles, newspaper articles of general circulation, scientific papers read in conferences, and published monographs and policy briefs. A number of valuable researches have been published amid COVID-19. The research work has been done during the lockdown using electronic resources, available databases, and online meetings using several video conferencing applications (Ray \& Srivastava, 2020).

Interestingly, one participant (P8) stressed the need to observe ethics in science to achieve public welfare. The observance of ethical considerations in the conduct of research is very important. Science teachers also need to follow ethical protocols in the knowledge creation process, specifically topics which are very sensitive.

Bulfin and Mathews (2003) stressed that teachers as knowledge producers are individuals who are able to construct valuable knowledge with and for others in communal environment. Hence, science teachers must continue to improve themselves through professional development activities in order to be legitimate knowledge creators, idea incubators, and innovation generators.

\section{Disruptive Innovator}

Science educators can also bring about change and innovation into the system, which goes outside the conventional ways and then improves over time. This role is called disruptive behavior. Participant 4 stressed that teachers have important roles to play in 'enlightening the general public on the negative effects of the virus' by bringing innovative ways of disseminating information through the teaching-learning process. Likewise, teachers can restructure the present curriculum and can infuse innovations to make the curriculum disruptive-free and future-ready. Such curriculum will be the kind of curriculum to be offered in future pandemics. Schools greatly need to fortify the curriculum practices and make them more relevant to the learners' educational needs even beyond the traditional classrooms (Toquero, 2020a).

Participant 8 emphasized the use of 'health information systems, big data and geo-localization to prevent and follow trajectories of the studied phenomenon.' Teachers may integrate teaching these skills to students as part of the science curriculum. Moreover, participant 5 shared that in the postpandemic setting, the use of robotics can have a bigger role in science teaching. He mentioned, 'mobile computing 
technology and augmented reality technologies are essential tools for education. He further mentioned about 'e-learning education, distance education, smart learning, blended learning and digital libraries as tools adapted to provide access to education that will help students connect with the world and understand issues that our world faces.' This implies the different innovations that science teachers can employ to develop digitally-literate, scientifically-literate, and techresponsible students.

Virtual learning and online teaching are emerging as novel platforms for science and engineering education, and it has fast-tracked the spread of educational resources worldwide (Hunter, 2015). The current situation has also shown an unavoidable dependence on out-of-date thinking and an unwillingness to view what digital technologies and the internet could bring to the student education and support advanced pedagogy and existing teaching strategies (Evans et al., 2020).

The unforeseen change brought about by COVID-19 pandemic requires major shifts in assessment culture and adds another dimension in educators' assessment practices in science education (Sarmiento et al., 2020). Sarmiento and colleagues (2020) recommended that educational institutions capitalize in technologies and infrastructures that could provide learning and the conduct of assessment, even when face-to-face setups are not conceivable, and ensure quality education delivery in different settings.

\section{Advocate against Misinformation}

In this digital age, educators also have a role to play in voicing out against false news and inaccurate information. One participant shared, "by being equipped with scientific knowledge, the people will avoid inappropriate information, that somehow leads to catastrophic public panic and mistakes' (P16). This shows the significant role of the information verification process and source assessment.

As a science teacher, he or she should advocate using valid, credible, verified, and bias-free information in reporting. In consonance with this, participant 3 reiterated that science educators must inculcate how to discern facts from bluffs, investigate the information, and prove its validity. If that can be done, then unnecessary mistakes might be avoided.' Misinformation can cause great havoc in public discourse, especially when shared online. Many people abruptly believe the things that they see online without even re-reading and cross-checking this information.

In the same vein, participant 8 mentioned that science teachers should be more active in teaching the students how to 'judge press reports, perspectives on fake news and how to detect and combat them, and critical reasoning about what people are saying.' In this way, students will be able to discern whether the information is evidence-based or otherwise. Another participant (P14) shared that teachers should make students reflect about the 'value of science and education' especially when sharing information to the general public. The COVID-19 pandemic gives a myriad of prospects to introduce students to sociological ways of thinking, scrutinizing data, and inquiring about human practices (Reiss, 2020).
The rising acceptance of digital technology globally has been complemented by the growing bane of false news (Lim \& Tan, 2020). With this, teachers are considered as stewards against misinformation and fake news. They need to inform students on the basic tenets of identifying the facts from the fakes. And thus, educators need to develop students as advocates of media literacy, ambassadors against fake information, and exponents of digital citizenship.

\section{Future-Ready Educator}

Being a future-ready educator is another role identified based on the narratives of the participants. This deals with how science teachers morph into the complexity of the present and future educational landscape. Salient responses along this theme include the following:

Strategize on the improvement of science education by relating it to past phenomena. $(P 10)$

Improve science education by making it more practical, not theoretical, for the students. Use COVID experience as inspiration on its drastic change. (P15)

I think science teachers should be trained further to practically prepare their students about disasters [natural and biological] and educate them on safety measures so that they behave accordingly in such events. (P13)

These statements reflect how science education can be reframed based on the COVID-19 experience. Future-ready teachers suggested that the science curriculum be enhanced from merely theoretical to be more pragmatic in its context. Another notable response said that it is important to integrate COVID-19 proper health practices and sanitation in science and health lessons' (P12). Health has become a prevailing concern that takes precedence over all other issues making health in policies become a reality, albeit in a way it was intended. Participant 8 also emphasized the importance of teaching personal hygiene and sanitation concepts in the science curriculum. This statement was seconded by Participant 9, who mentioned that students' awareness of personal hygiene and maintaining healthy lifestyle is of utmost importance.

Relatedly, participant 12 shared that teachers need to ensure that the science curriculum remains relevant in the post-pandemic setting. Science teachers need to continuously reframe the science curriculum with the current and emerging needs. Reiss (2020) averred that science curriculum, teaching strategies, and assessment tools should not be changed in a "knee-jerk reaction whenever some new science-related issue arises” (p. 1090).

Usak and colleagues (2020) articulated that "fear of the future arises from the past and the present and is a reflection of what is accumulated to the present" (p. 180). Hence it is important to develop preparedness in crises such as the current health emergency due to COVID-19. With what we experienced in this global contagion, schools need to craft more pandemic-resilient and future-ready curriculum to avoid learning losses with the help of the government and the stakeholders. 


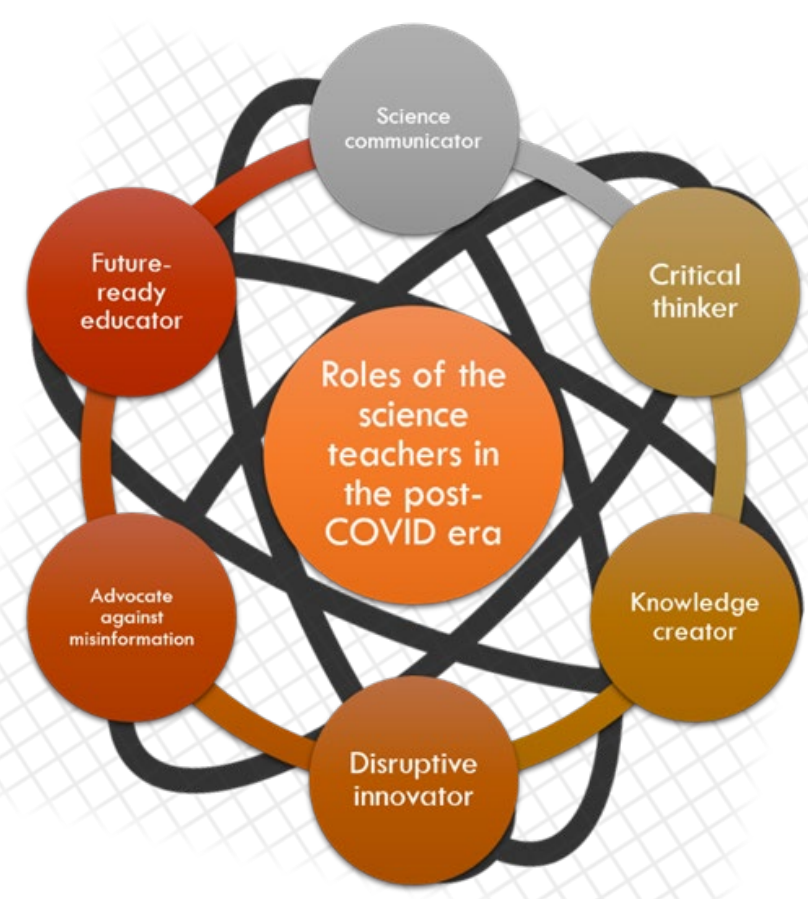

Figure 1. Roles of the Science Teachers in the post-COVID era

The conceptual framework was developed to describe the roles of science educators in the post-COVID milieu (Figure 1).

The conceptual framework developed can inform educational institutions with the roles of science teachers in the post-pandemic setting. It can also help teacher training institutions to integrate the model in preservice teacher education as this can help them be aware of their essential roles in preventing future pandemics. The framework is shaped like an atom since atom is a building block for all matter in the universe. In consonance, science teachers also serve as important building blocks of society who assume varied roles to contribute towards societal transformation and social action.

More than the roles of science teachers identified in this research, it is also important to recognize the other roles of science educators in the society in the post-pandemic setting. Teachers are seen as catalysts of social change (Bourn, 2016; Iskandar \& Zulela, 2021; Madondo, 2020), advocates of inclusion and social justice (Pantic \& Carr, 2017), stewards of sustainable peace, social cohesion and development (Rubagiza et al., 2016), communicators of information (Esteve, 2000; Negrete \& Lartigue, 2004), exponents of socio-scientific issues (Nuangchalerm, 2009), and digital networkers (Kim, 2002). It is therefore imperative for science educators to be versatile in assuming varied roles from learning advocates, to change enablers, and to contributors to knowledge-based economy. Science educators' roles will be redefined and reframed in the post-pandemic setting in the context of the VUCAD ${ }^{2}$ world.

\section{CONCLUSION AND IMPLICATIONS}

The study explored the roles of science educators as vital players in the post-COVID milieu. This qualitative inquiry found out that science educators play varied significant roles as science communicators, critical thinkers, knowledge creators, disruptive innovators, advocates against misinformation, and future-ready educators in the postpandemic setting. The conceptual paradigm crafted as an output of the study could inform the educational institutions on the vital roles of science educators in the post-pandemic era in the perspective of the VUCAD ${ }^{2}$ world.

The study has several implications for pedagogy and policies. For pedagogical implications, the conceptual paradigm may be part of the special topics in teaching the Science Technology and Society (STS) and History and Philosophy of Science (HPS) courses. This can also be integrated into professional education courses for science education students. Science education curriculum should also emphasize environmental education with a focus on health and sanitation to develop more aware and environmentallyresponsible citizens. For practice, the administration should support science teachers for their continuing professional development activities to help prevent and respond to future pandemics as a learning facilitator. Teachers should also be supported in terms of research grants and funding for them to be able to contribute to research-based and evidence-based practices in their areas of expertise.

\section{LIMITATIONS AND FUTURE RESEARCH}

The results of this qualitative inquiry reflect the different roles that science educators may assume in the post-COVID educational setting. Furthermore, the study offers policy and pedagogical implications in science teachers' vital roles in the post-pandemic environment. However, due to the qualitative nature of the study, some limitations must be pondered. First, the roles identified were based mainly on the participants' qualitative responses and not based on a survey questionnaire. Second, the participants were limited only to 16 teachers, which may not fully represent the majority of science educators' perceived roles.

Lastly, no statistical analysis was employed in the present study. Hence, the investigators suggest that further studies should be done to confirm the present findings quantitatively. Additionally, profiling of teachers may be considered to enrich the results further. Likewise, future research may also consider looking at all teachers' roles regardless of specialization to give a clearer picture of the teachers' roles in the post-COVID milieu and how they can help prevent and respond to future pandemics as a learning facilitator.

Author contributions: All co-authors have involved in all stages of this study while preparing the final version. They all agree with the results and conclusions.

Funding: No external funding is received for this article.

Acknowledgements: The authors would like to express their most profound gratitude to the support of the President Ramon Magsaysay State University - San Marcelino Campus, and to the science teachers, despite the challenging times, have willingly and actively participated in the online data collection. To the editors and peer reviewers for the constructive feedback which enhanced this research article.

Declaration of interest: The authors declare that they have no competing interests. 
Ethics approval and consent to participate: Not applicable. Availability of data and materials: All data generated or analyzed during this study are available for sharing when appropriate request is directed to corresponding author.

\section{REFERENCES}

Acikgoz, O., \& Gunay, A. (2020). The early impact of the Covid19 pandemic on the global and Turkish economy. Turkish Journal of Medical Sciences, 50(SI-1), 520-526. https://doi.org/10.3906/sag-2004-6

Adams, J., Avraamidou, L., Bayram-Jacobs, D., Boujaoude, S., Bryan, L., Christodoulou, A., Couso, D A. Danielsson, A., Dillon, J., \& Erduran, S. (2018). The role of science education in a changing world. NIAS Lorentz Center.

Atalan, A. (2020). Is the lockdown important to prevent the COVID-19 pandemic? Effects on psychology, environment and economy-perspective. Annals of Medicine and Surgery, 56, 38-42. https://doi.org/10.1016/j.amsu.2020.06.010

Bourn, D. (2016). Teachers as agents of social change. International Journal of Development Education and Global Learning, 7(3), 63-77. https://doi.org/10.18546/ ijdegl.07.3.05

Bruns, D. P., Kraguljac, N. V., \& Bruns, T. R. (2020). COVID19: facts, cultural considerations, and risk of stigmatization. Journal of Transcultural Nursing, 31(4), 326332. https://doi.org/10.1177/1043659620917724

Bulfin, S., \& Mathews, K. (2003). Reframing beginning English teachers as knowledge producers: Learning to teach and transgress. English Teaching, 2(3), 47-58.

Burns, T. W., O’Connor, D. J., \& Stocklmayer, S. M. (2003). Science communication: A contemporary definition. Public Understanding of Science, 12(2), 183-202. https://doi.org/10.1177/09636625030122004

Butera, F., Batruch, A., Autin, F., Mugny, G., Quiamzade, A., \& Pulfrey, C. (2021). Teaching as social influence: Empowering teachers to become agents of social change. Social Issues and Policy Review, 15(1), 323-355. https://doi.org/10.1111/sipr.12072

Cahapay, M. B. (2020). Rethinking education in the new normal post-COVID-19 era: A curriculum studies perspective. Aquademia, 4(2), ep20018. https://doi.org/10.29333/aquademia/8315

Cappy, C. L. (2016). Shifting the future? Teachers as agents of social change in South African secondary schools. Education as Change, 20(3), 119-140. https://doi.org/10.17159/1947-9417/2016/1314

Cuaton, G. P. (2020). Philippines higher education institutions in the time of COVID-19 pandemic. Revista Românească pentru Educaţie Multidimensională, 12(1 Sup2), 61-70. https://doi.org/10.18662/rrem/12.1sup2/247

Dodds, K., Broto, V. C., Detterbeck, K., Jones, M., Mamadouh, V., Ramutsindela, M., Varsanyi, M., Wachsmuth, D., \& Woon, C. Y. (2020). The COVID-19 pandemic: Territorial, political and governance dimensions of the crisis. Territory, Politics, Governance, 8(3), 289-298. https://doi.org/10.1080 /21622671.2020.1771022
Esteve, J. M. (2000). The transformation of the teachers' role at the end of the twentieth century: New challenges for the future. Educational Review, 52(2), 197-207. https://doi.org/10.1080/713664040

Evans, D. J., Bay, B. H., Wilson, T. D., Smith, C. F., Lachman, N., \& Pawlina, W. (2020). Going virtual to support anatomy education: A STOPGAP in the midst of the Covid-19 pandemic. Anatomical Sciences Education, 13(3), 279-283. https://doi.org/10.1002/ase.1963

Faulkner, S. L., \& Trotter, S. P. (2017). Data saturation. The International Encyclopedia of Communication Research Methods, 1-2. https://doi.org/10.1002/9781118901731. iecrm0060

Fernandes, N. (2020). Economic effects of coronavirus outbreak (COVID-19) on the world economy. http://dspace.khazar.org /bitstream/20.500.12323/4496/1/Economic\%20Effects\%20 of\%20Coronavirus\%200utbreak.pdf

Haghparast, M., Nasaruddin, F. H., \& Abdullah, N. (2014). Cultivating critical thinking through e-learning environment and tools: A review. Procedia-Social and Behavioral Sciences, 129, 527-535. https://doi.org/10.1016/ j.sbspro.2014.03.710

Hunter, P. (2015). The virtual university: Digital tools for elearning and remote learning are becoming an increasingly important tool for teaching at universities. EMBO Reports, 16(2), 146-148. https://doi.org/10.15252/embr.201440016

Ilisko, D. (2007). Teachers as agents of societal change. Journal of Teacher Education for Sustainability, 7(1), 14-26. https://doi.org/10.2478/v10099-009-0002-9

Iskandar, R., \& Zulela, M. S. (2021). Professionality analysis of basic education teachers as agents to improve creativity in digital era. Jurnal Ilmiah Sekolah Dasar, 5(1), 16-24.

Jermolajeva, J., Bogdanova, T., \& Silchenkova, S. (2019). School teacher outside of class: Self-reflection of pedagogues from Latvia and Russia on their cooperation with colleagues. Sabiedrība. Integrācija. Izglītība (Society. Integration. Education), 2, 147-155. https://doi.org/ 10.17770/sie2019vol2.3866

Karakaya, F., Adiguzel, M., Ucuncu, G., Çimen, O., \& Yilmaz, M. (2021). Teachers' views towards the effects of COVID19 pandemic in the education process in turkey. Participatory Educational Research, 8(2), 17-30. https://doi.org/10.17275/per.21.27.8.2

Kass, E., \& Miller, E. C. (2011). Bedouin special-education teachers as agents of social change. Teaching and Teacher Education, 27(4), 788-796. https://doi.org/10.1016/ j.tate.2011.01.004

Keswani, R. N., Sethi, A., Repici, A., Messmann, H., \& Chiu, P. W. (2020). How to maximize trainee education during the coronavirus disease-2019 pandemic: Perspectives from around the world. Gastroenterology, 159(1), 26-29. https://doi.org/10.1053/j.gastro.2020.05.012

Kim, C. Y. (2002). Teachers in digital knowledge-based society: new roles and vision. Asia Pacific Education Review, 3(2), 144-148. https://doi.org/10.1007/bf03024907 
Korkmaz, O., Çakir, R., \& Ozden, M. Y. (2017). A validity and reliability study of the computational thinking scales (CTS). Computers in Human Behavior, 72, 558-569. https://doi.org/10.1016/j.chb.2017.01.005

Korkmaz, O., Çakir, R., \& Ugur-Erdogmus, F. (2020). A validity and reliability study of the basic STEM skill levels perception scale. International Journal of Psychology and Educational Studies, 7(2), 111-121. https:/doi.org/ 10.17220/ijpes.2020.02.010

Lim, S. S., \& Tan, K. R. (2020). Front liners fighting fake news: Global perspectives on mobilising young people as media literacy advocates. Journal of Children and Media, 14(4), 529-535. https://doi.org/10.1080/17482798.2020.1827817

Lochmiller, C. R., \& Lester, J. N. (2017). An introduction to educational research: Connecting methods to practice. SAGE Publications, Inc.

Madhav, N., Oppenheim, B., Gallivan, M., Mulembakani, P., Rubin, E., \& Wolfe, N. (2017). Pandemics: risks, impacts, and mitigation. In Disease control priorities, $3 r d E d$. (Vol. 9): Improving health and reducing poverty; International Bank for Reconstruction and Development/The World Bank, pp. 315-345. https://doi.org/10.1596/978-1-4648-0527-1_ch17

Madondo, F. (2020). Perceptions on curriculum implementation: A Case for rural Zimbabwean early childhood development teachers as agents of change. Journal of Research in Childhood Education, 1-18. https://doi.org/10.1080/02568543.2020.1731024

Marinoni, G., Van’t Land, H., \& Jensen, T. (2020). The impact of Covid-19 on higher education around the world. IAU Global Survey Report. https://www.iau-aiu.net/IAU-GlobalSurvey-on-the-Impact-of-COVID-19-on-HigherEducation-around-the

Mendenhall, M., Cha, J., Falk, D., Bergin, C., \& Bowden, L. (2021). Teachers as agents of change: positive discipline for inclusive classrooms in Kakuma refugee camp. International Journal of Inclusive Education, 25(2), 147-165. https://doi.org/10.1080/13603116.2019.1707300

Miles, M. B., Huberman, M., \& Saldaña, J. (2014). Qualitative data analysis: A methods sourcebook (3rd ed.). SAGE Publications, Inc. https://doi.org/10.1016/S03014622(98)00172-0

Morales, M. P. E. (2019). Education in a VUCA (volatile, uncertain, complex, ambiguous) world. The Normal Lights, 13(2), v-x.

Morales, M. P. E. (2020). VUCAD2: A focus on the D’s. Asia Pacific Higher Education Research Journal, 7(1), vii-ix.

Moralista, R. B., \& Oducado, R. M. F. (2020). Faculty perception toward online education in a state college in the philippines during the coronavirus disease 19 (COVID-19) Pandemic. Universal Journal of Educational Research, 8(10), 4736-4742. https://doi.org/10.13189/ujer.2020.081044

Muhammad, S., Long, X., \& Salman, M. (2020). COVID-19 pandemic and environmental pollution: a blessing in disguise?. Science of The Total Environment, 728, 138820. https://doi.org/10.1016/j.scitotenv.2020.138820
Negrete, A., \& Lartigue, C. (2004). Learning from education to communicate science as a good story. Endeavour, 28(3), 120-124. https://doi.org/10.1016/j.endeavour.2004.07.003

Noel, T. K. (2020). Conflating culture with COVID-19: Xenophobic repercussions of a global pandemic. Social Sciences \& Humanities Open, 2(1), 100044. https://doi.org/10.1016/j.ssaho.2020.100044

Novelli, M., \& Sayed, Y. (2016). Teachers as agents of sustainable peace, social cohesion and development: Theory, practice \& evidence. Education as Change, 20(3), 15-37. https://doi.org/10.17159/1947-9417/2016/1486

Nuangchalerm, P. (2009). Development of socioscientific issues-based teaching for preservice science teachers. Journal of Social Sciences, 5(3), 239-243. https://doi.org/10.3844/jssp.2009.239.243

Paital, B. (2020). Nurture to nature via COVID-19, a selfregenerating environmental strategy of environment in global context. Science of the Total Environment, 139088. https://doi.org/10.1016/j.scitotenv.2020.139088

Paital, B., \& Agrawal, P. K. (2020). Air pollution by NO 2 and PM 2.5 explains COVID-19 infection severity by overexpression of angiotensin-converting enzyme 2 in respiratory cells: a review. Environmental Chemistry Letters, 1-18. https://doi.org/10.1007/s10311-020-01091-w

Paital, B., Das, K., \& Parida, S. K. (2020). Inter nation social lockdown versus medical care against COVID-19, a mild environmental insight with special reference to India. Science of the total environment, 138914. https://doi.org/10.1016/j.scitotenv.2020.138914

Pantic, N., \& Carr, D. (2017). Educating teachers as agents of social justice: A virtue ethical perspective. In Teacher Education for the Changing Demographics of Schooling (pp. 55-65). Springer. https://doi.org/10.1007/978-3-31954389-5_5

Pantic, N., \& Florian, L. (2015). Developing teachers as agents of inclusion and social justice. Education Inquiry, 6(3), 27311. https://doi.org/10.3402/edui.v6.27311

Pfefferbaum, B., \& North, C. S. (2020). Mental health and the Covid-19 pandemic. New England Journal of Medicine, 383(6), 510-512. https://doi.org/10.1056/nejmp2008017

Radwan, A., \& Radwan, E. (2020). Social and economic impact of school closure during the outbreak of the COVID-19 pandemic: A quick online survey in the Gaza Strip. Pedagogical Research, 5(4), em0068. https://doi.org/ $10.29333 / \mathrm{pr} / 8254$

Ray, S., \& Srivastava, S. (2020). Virtualization of science education: A lesson from the COVID-19 pandemic. Journal of Proteins and Proteomics, 11, 77-80. https://doi.org/ 10.1007/s42485-020-00038-7

Reiss, M. J. (2020). Science education in the light of COVID-19. Science \& Education, 29(4), 1079-1092. https://doi.org/ 10.1007/s11191-020-00143-5

Restubog, S. L. D., Ocampo, A. C. G., \& Wang, L. (2020). Taking control amidst the chaos: Emotion regulation during the COVID-19 pandemic. Journal of Vocational Behavior, 119, 103440. https://doi.org/10.1016/j.jvb.2020.103440 
Rogayan, D. V. Jr. (2018). Why Young Filipino Teachers Teach?. Asia Pacific Higher Education Research Journal, 5(2), 48-60.

Rogayan, D. V. Jr., Luna, L. A. N., \& Dizon, X. P. (2021). Filipino university students' knowledge, attitude and practices towards COVID-19. Preprint.

Rubagiza, J., Umutoni, J., \& Kaleeba, A. (2016). Teachers as agents of change: Promoting peacebuilding and social cohesion in schools in Rwanda. Education as Change, 20(3), 202-224. https://doi.org/10.17159/1947-9417/2016/1533

Sahu, P. (2020). Closure of universities due to Coronavirus Disease 2019 (COVID-19): impact on education and mental health of students and academic staff. Cureus, 12(4), e7541. https://doi.org/10.7759/cureus.7541

Sarmiento, C. P., Morales, M. P. E., Elipane, L. E., \& Palomar, B. C. (2020). Assessment practices in Philippine higher STEAM education. Journal of University Teaching \& Learning Practice, 17(5), Art. 18.

Savin-Baden, M., \& Niekerk, L. V. (2007). Narrative inquiry: Theory and practice. Journal of Geography in Higher Education, 31(3), 459-472. https://doi.org/10.1080/ 03098260601071324

Shakil, M. H., Munim, Z. H., Tasnia, M., \& Sarowar, S. (2020). COVID-19 and the environment: A critical review and research agenda. Science of the Total Environment, 141022. https://doi.org/10.1016/j.scitotenv.2020.141022

Sintema, E. J. (2020). Effect of COVID-19 on the performance of grade 12 students: Implications for STEM education. Eurasia Journal of Mathematics, Science and Technology Education, 16(7), em1851. https://doi.org/10.29333/ejmste/ 7893

Sirakaya, M., Alsancak Sirakaya, D., \& Korkmaz, O. (2020). The impact of STEM attitude and thinking style on computational thinking determined via structural equation modeling. Journal of Science Education and Technology, 112. https://doi.org/10.1007/s10956-020-09836-6

So, K., \& Park, N. (2020). Can teachers be change agents? A critical analysis of teacher images in school reform policies. The Asia-Pacific Education Researcher, 1-10. https://doi.org/10.1007/s40299-020-00536-8

Sokolovskaya, I. E. (2020). Socio-psychological factors of students satisfaction in the context of digitalization of education during the COVID-19 pandemic and selfisolation. Digital Sociology, 3(2), 46-54. https://doi.org/ $10.26425 / 2658-347 x-2020-2-46-54$

Sundarasen, S., Chinna, K., Kamaludin, K., Nurunnabi, M., Baloch, G. M., Khoshaim, H. B., Hossain, S.F.A., \& Sukayt, A. (2020). Psychological impact of COVID-19 and lockdown among university students in Malaysia: Implications and policy recommendations. International Journal of Environmental Research and Public Health, 17(17), 6206. https://doi.org/10.3390/ijerph17176206
Tee, M. L., Tee, C. A., Anlacan, J. P., Aligam, K. J. G., Reyes, P. W. C., Kuruchittham, V., \& Ho, R. C. (2020). Psychological impact of COVID-19 pandemic in the Philippines. Journal of Affective Disorders, 277, 379-391. https://doi.org/10.1016 /j.jad.2020.08.043

Toquero, C. M. (2020a). Challenges and opportunities for higher education amid the COVID-19 pandemic: The Philippine context. Pedagogical Research, 5(4), em0063. https://doi.org/10.29333/pr/7947

Toquero, C. M. D. (2020b). Will COVID-19 bring the armageddon? expanding psychosocial support and environmental care: An autoethnographic research. Aquademia, 4(2), ep20022. https://doi.org/10.29333/ aquademia/8438

Tria, J. Z. (2020). The COVID-19 pandemic through the lens of education in the Philippines: The new normal. International Journal of Pedagogical Development and Lifelong Learning, 1(1), 2-4. https://doi.org/10.30935/ ijpdll/8311

Unicef Australia (2020). How teachers can talk to students about coronavirus disease (COVID-19): Tips for having age appropriate discussions to reassure and protect children. https://www.unicef.org/coronavirus/how-teachers-cantalk-children-about-coronavirus-disease-covid-19

United Nations World Tourism Organization (UNWTO). (2020). Impact assessment of COVID-19 outbreak on international tourism. https://www.unwto.org/impactassessment-of-the-covid-19-outbreak-oninternationaltourism

Usak, M., Masalimova, R. A., Cherdymova, I. E., \& Shaidullina, R. A. (2020). New playmaker in science education: COVID19. Journal of Baltic Science Education, 19(2), 180185. https://doi.org/10.33225/jbse/20.19.00

Verma, A., \& Prakash, S. (2020). Impact of COVID-19 on environment and society. Journal of Global Biosciences, 9(5), $7352-7363$

Waller, R. E., Lemoine, P. A., Mense, E. G., Garretson, C. J., \& Richardson, M. D. (2019). Global higher education in a VUCA world: Concerns and projections. Journal of Education and Development, 3(2), 73-83. https://doi.org/ 10.20849/jed.v3i2.613

Woods, E. T., Schertzer, R., Greenfeld, L., Hughes, C., \& MillerIdriss, C. (2020). COVID-19, nationalism, and the politics of crisis: A scholarly exchange. Nations and Nationalism, 26 (4), 807-825. https://doi.org/10.1111/nana.12644

World Health Organization. (2020). COVID-19 global risk communication and community engagement strategy, December 2020-May 2021: interim guidance, 23 December 2020 (No. WHO/2019-nCoV/RCCE/2020.3). World Health Organization.

https://apps.who.int/iris/handle/10665/338057 